\title{
Lactone Derivatives Produced by a Phaeoacremonium sp., an Endophytic Fungus from Senna spectabilis
}

Geraldo H. Silva, ${ }^{\dagger}$ Maria L. Zeraik, ${ }^{\ddagger}$ Camila M. de Oliveira, ${ }^{\S}$ Helder L. Teles, ${ }^{\perp}$ Henrique C. Trevisan, Ludwig H. Pfenning," Camila P. Nicolli, " Maria C. M. Young, "Yvonne P. Mascarenhas, ${ }^{\text {, }}$

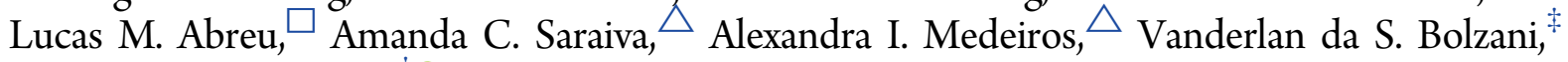
and Angela R. Araujo*,

${ }^{\dagger}$ Instituto de Ciências Exatas e Tecnológicas, Universidade Federal de Viçosa, Rio Paranaíba, Minas Gerais 38810-000, Brazil ${ }^{\ddagger}$ Department of Organic Chemistry, São Paulo State University (Unesp), Chemistry Institute, Araraquara, São Paulo 14800-900, Brazil

${ }^{\S}$ Instituto de Ciências Exatas e Tecnologia, Universidade Federal do Amazonas, Itacoatiara, Amazonas 69103-128, Brazil

${ }^{\perp}$ Instituto de Ciências Exatas e Naturais, Universidade Federal de Mato Grosso, Rondonópolis, Mato Grosso 78735-901, Brazil

"Departamento de Fitopatologia, Universidade Federal de Lavras, Lavras, Minas Gerais 37200-000, Brazil

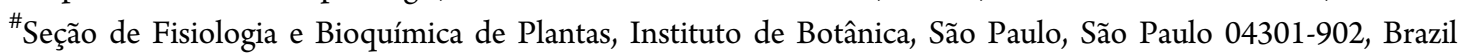

IIInstituto de Física de São Carlos, Universidade de São Paulo, São Carlos, São Paulo 13560-970, Brazil

$\square$ Departamento de Fitopatologia, Universidade Federal de Viçosa, Viçosa, Minas Gerais 36570000, Brazil

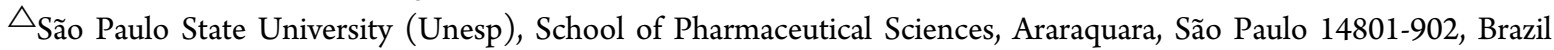

Supporting Information

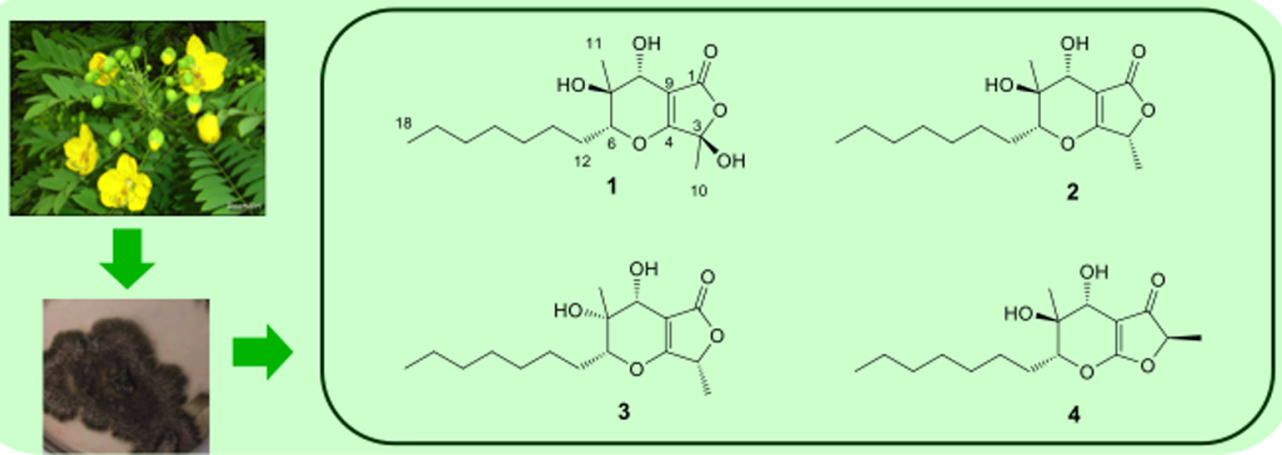

ABSTRACT: Three new isoaigialones, A, B, and C (1-3), along with aigialone (4), were isolated from the crude EtOAc extract of a Phaeoacremonium sp., an endophytic fungus obtained from the leaves of Senna spectabilis. The structures of these compounds were elucidated based on the analysis of spectroscopic data. Compounds $\mathbf{2}$ and $\mathbf{4}$ were active against the phytopathogenic fungi Cladosporium cladosporioides and C. sphaerospermum. This is the first report of metabolites produced by an Phaeoacremonium sp., associated with S. spectabilis.

$\mathrm{A}_{\mathrm{i}}^{\mathrm{p}}$ pproximately one-quarter of all natural products have been isolated from fungi, ${ }^{1}$, which are estimated to be $1.5-5.5$ million species, ${ }^{2}$ including mycoparasites, coprophiles, those from soil and freshwater, epiphytes, endophytes, and others. Endophytic fungi inhabit the interior of a plant during the fungus life cycle, without harming the plant. ${ }^{3}$ A number of potently bioactive and structurally diverse secondary metabolites have been isolated from endophytic fungi, ${ }^{4-6}$ which are considered a promising source of novel products. ${ }^{6}$

In our continuing program studying metabolites from endophytic fungi, ${ }^{7-12}$ we investigated endophytes associated with the plant Senna spectabilis (Leguminoseae), selected because several species of Senna accumulate unusual phenolic compounds. ${ }^{13}$ Chapla et al. ${ }^{12}$ described the isolation of bioactive phenolic compounds, including alternariol, $5^{\prime}$ epialtenuene, and cytosporone $\mathrm{C}$, produced by the endophytic fungus Phomopsis sp., associated with S. spectabilis. These results, together with the hypothesis that endophytic fungi are capable of mimicking the chemistry of their hosts, ${ }^{13}$ led us to investigate endophytic fungi associated with S. spectabilis.

Here, we describe the isolation, structure, and biological activity (antifungal and cytotoxic) of three new isoaigialones, $\mathrm{A}$,

Received: September 14, 2015

Published: April 20, 2017 


\section{Chart 1}
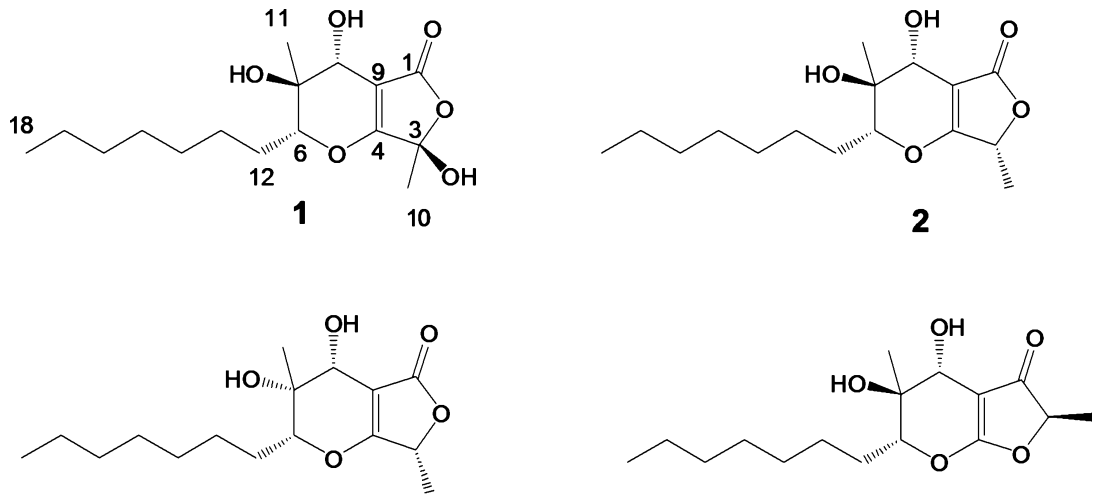

3

Table 1. ${ }^{1} \mathrm{H}$ and ${ }^{13} \mathrm{C}$ NMR Data for Isoaigialones $1-3$, at 500 and $125 \mathrm{MHz}$

\begin{tabular}{|c|c|c|c|c|c|c|}
\hline \multirow[b]{2}{*}{ position } & \multicolumn{2}{|c|}{1} & \multicolumn{2}{|c|}{2} & \multicolumn{2}{|c|}{3} \\
\hline & $\delta_{\mathrm{C}}$ (mult.) & $\delta_{\mathrm{H}}($ mult., $J$ in $\mathrm{Hz}$ ) & $\delta_{\mathrm{C}}$ (mult.) & $\delta_{\mathrm{H}}$ (mult., $J$ in $\mathrm{Hz}$ ) & $\delta_{\mathrm{C}}$ (mult.) & $\delta_{\mathrm{H}}($ mult., $J$ in $\mathrm{Hz}$ ) \\
\hline 1 & 168.8, C & & 171.1, C & & 171.1, C & \\
\hline 2 & & & & & & \\
\hline 3 & 99.9, C & & $72.5, \mathrm{CH}$ & $4.90, \mathrm{q}(7.5)$ & 72.7, CH & $4.89, \mathrm{q}(6.5)$ \\
\hline 4 & 172.3, C & & 175.8, C & & 176.0, C & \\
\hline 6 & 87.2, $\mathrm{CH}$ & 4.10, br d $(11.0)$ & 87.2, $\mathrm{CH}$ & 4.10, br d $(12.5)$ & 87.4, CH & 4.08, br d $(11.0)$ \\
\hline 7 & 70.7, C & & 70.7, C & & 70.6, C & \\
\hline 8 & $64.8, \mathrm{CH}$ & $3.80, \mathrm{~s}$ & 64.5, CH & 3.79 , br d $(6.0)$ & 64.8, CH & $3.88, \mathrm{~s}$ \\
\hline 9 & 101.2, C & & 100.4, C & & 100.5, C & \\
\hline 10 & 23.3, $\mathrm{CH}_{3}$ & $1.48, \mathrm{~s}$ & 17.6, $\mathrm{CH}_{3}$ & $1.31, \mathrm{~d}(7.5)$ & 17.3, $\mathrm{CH}_{3}$ & $1.32, \mathrm{~d}(6.5)$ \\
\hline 11 & 20.0, $\mathrm{CH}_{3}$ & $1.18, \mathrm{~s}$ & 17.6, $\mathrm{CH}_{3}$ & $1.19, \mathrm{~s}$ & 20.4, $\mathrm{CH}_{3}$ & $1.19, \mathrm{~s}$ \\
\hline 12 & 27.6, $\mathrm{CH}_{2}$ & $1.80, \mathrm{~m}$ & 27.7, $\mathrm{CH}_{2}$ & $1.90, \mathrm{~m}$ & 27.8, $\mathrm{CH}_{2}$ & $1.83, \mathrm{~m}$ \\
\hline 13 & 26.3, $\mathrm{CH}_{2}$ & $1.54, \mathrm{~m}$ & 26.2, $\mathrm{CH}_{2}$ & $1.50, \mathrm{~m}$ & 26.4, $\mathrm{CH}_{2}$ & $1.43, \mathrm{~m}$ \\
\hline 14 & 28.6, $\mathrm{CH}_{2}$ & $1.24, \mathrm{~m}$ & 28.4, $\mathrm{CH}_{2}$ & $1.20, \mathrm{~m}$ & 28.6, $\mathrm{CH}_{2}$ & $1.24, \mathrm{~m}$ \\
\hline 15 & 28.5, $\mathrm{CH}_{2}$ & $1.24, \mathrm{~m}$ & 28.4, $\mathrm{CH}_{2}$ & $1.20, \mathrm{~m}$ & 28.5, $\mathrm{CH}_{2}$ & $1.24, \mathrm{~m}$ \\
\hline 16 & 31.1, $\mathrm{CH}_{2}$ & $1.24, \mathrm{~m}$ & 31.1, $\mathrm{CH}_{2}$ & $1.20, \mathrm{~m}$ & 31.2, $\mathrm{CH}_{2}$ & $1.24, \mathrm{~m}$ \\
\hline 17 & 21.9, $\mathrm{CH}_{2}$ & $1.24, \mathrm{~m}$ & 21.9, $\mathrm{CH}_{2}$ & $1.20, \mathrm{~m}$ & 22.0, $\mathrm{CH}_{2}$ & $1.24, \mathrm{~m}$ \\
\hline 18 & 13.9, $\mathrm{CH}_{3}$ & $0.85, \mathrm{t}(7.5)$ & $13.8, \mathrm{CH}_{3}$ & $0.84, \mathrm{t}(7.5)$ & 13.9, $\mathrm{CH}_{3}$ & $0.85, \mathrm{t}(7.5)$ \\
\hline 7-OH & & & & $4.84, \mathrm{~s}$ & & 5.40, br s \\
\hline $8-\mathrm{OH}$ & & & & $5.36, \mathrm{~d}(6.0)$ & & $4.80, \mathrm{~s}$ \\
\hline
\end{tabular}

$\mathrm{B}$, and $\mathrm{C}(1-3)$, along with aigialone $(4)^{14}$ from a Phaeoacremonium sp. associated with $S$. spectabilis. These compounds are considered rare in nature due to a ketene acetal functional group. ${ }^{14}$

The chemical and biological evaluation of six endophytic axenic strains (CL-01-CL-06) isolated from leaves of S. spectabilis was conducted in order to prioritize these for additional studies. The crude extract of strain CL-06, classified as Phaeoacremonium sp., displayed antifungal activity against the phytopathogenic fungi Cladosporium cladosporioides and C. sphaerospermum; the endophytic fungus selected yielded three new isoaigialones, A (1), B (2), and C (3), and the known aigialone (4).

Compound 1 was isolated as an optically active, white, amorphous powder. The molecular formula of $\mathbf{1}$ was established as $\mathrm{C}_{16} \mathrm{H}_{26} \mathrm{O}_{6}$ by HRESIMS analysis. The UV spectrum of 1 showed an intense absorption at $\lambda_{\max } 235 \mathrm{~nm}$, while the IR spectrum presented bands at $\nu_{\max } 3336(\mathrm{OH})$, $1736(\mathrm{C}=\mathrm{O})$, and $1677 \mathrm{~cm}^{-1}$ (enol).

Analysis of NMR data of $\mathbf{1}$ (Table 1) indicated the presence of two olefinic carbons, three methyl groups, two O-substituted $\mathrm{sp}^{3}$ carbons, two oxymethine groups, six methylene carbons, and one signal at $\delta_{\mathrm{C}} 168.8 \mathrm{ppm}$ in the ${ }^{13} \mathrm{C}$ NMR spectrum, which suggested the presence of an ester group. The MS and NMR data indicated the presence of two cyclic systems in the molecule.

Analysis of the ${ }^{1} \mathrm{H}$ and ${ }^{13} \mathrm{C}$ NMR data (Table 1) indicated the presence of an $n$-heptyl moiety. A methylene group at $\delta_{\mathrm{H}}$ 1.80 showed coupling with a methylene at $\delta_{\mathrm{H}} 1.54$, itself coupled to a methylene at $\delta_{\mathrm{H}} 1.24$ connected to the methyl group at $\delta_{\mathrm{H}} 0.85$. The $n$-heptyl group was shown to be connected to $\mathrm{C}-6$ via a long-range correlation observed in the HMBC spectrum between $\mathrm{H}-6\left(\delta_{\mathrm{H}} 4.10\right)$ and C-13 $\left(\delta_{\mathrm{C}} 26.3\right)$. A vicinal ${ }^{1} \mathrm{H}-{ }^{1} \mathrm{H}$ correlation between $\mathrm{H}-6$ and $\mathrm{H}-12\left(\delta_{\mathrm{H}} 1.80\right)$ observed in the COSY spectrum confirmed this connection. In the HMBC spectrum, H-6 showed correlations to both C-7 $\left(\delta_{\mathrm{C}}\right.$ $70.7)$ and $\mathrm{C}-4\left(\delta_{\mathrm{C}} 172.3\right)$. The hydrogen $\mathrm{H}-8\left(\delta_{\mathrm{H}} 3.80\right)$ showed long-range correlations to C-6 $\left(\delta_{\mathrm{C}} 87.2\right), \mathrm{C}-4\left(\delta_{\mathrm{C}} 172.3\right)$, and C-1 $\left(\delta_{\mathrm{C}} 168.8\right)$, while the methyl group C-11 showed correlations to C- 6 and C-8. These data enabled us to establish the structure of the 3,4-dihydro-3-methyl-2-heptyl- $2 \mathrm{H}$-pyran3,4-diol moiety in 1. Finally, correlations observed in the gHMBC spectrum between $\mathrm{H}_{3} \mathrm{C}-10$ and $\mathrm{C}-3$ and C-4, along with the UV absorption and the ${ }^{13} \mathrm{C}$ NMR chemical shifts of $\mathrm{C}$ - 
$1\left(\delta_{\mathrm{C}} 168.8\right), \mathrm{C}-4\left(\delta_{\mathrm{C}} 172.3\right)$, and C-9 $\left(\delta_{\mathrm{C}} 101.2\right)$, indicated the presence of a $\beta$-alkoxy- $\alpha, \beta$-unsaturated lactone fragment in $\mathbf{1}^{15}$

These data allowed us to establish the planar structure of $\mathbf{1}$. The structure assignment, as well as its relative configuration, was finally confirmed by X-ray analysis (Figure 1).

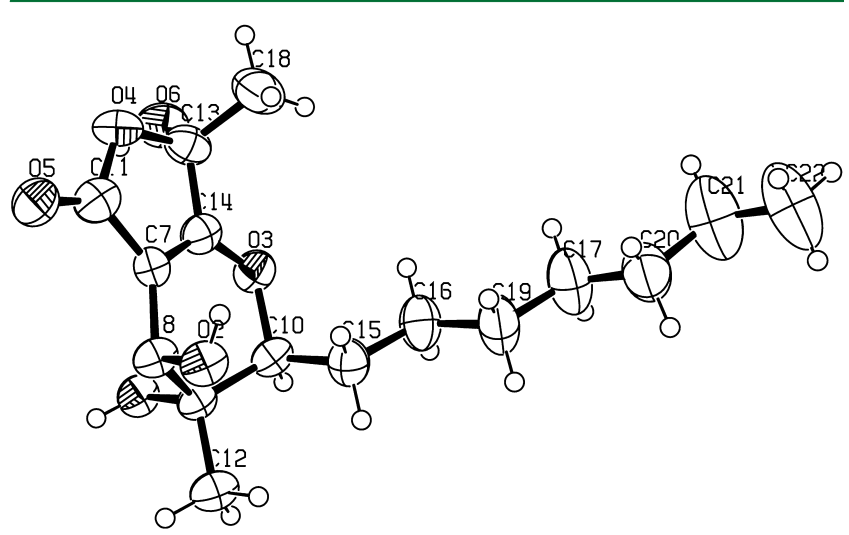

Figure 1. Thermal ellipsoid representation of $\mathbf{1}$.

Compound 2 was isolated as an optically active, white, amorphous powder, with the formula $\mathrm{C}_{16} \mathrm{H}_{26} \mathrm{O}_{5}$ based on analysis by HRESIMS and ${ }^{1} \mathrm{H}$ and ${ }^{13} \mathrm{C}$ NMR data (Table 1 ). The ${ }^{1} \mathrm{H}$ and ${ }^{13} \mathrm{C}$ NMR spectra (Table 1 ) of 2 were very similar to that of isoaigialone $\mathrm{A}(\mathbf{1})$, differing in the chemical shift of $\mathrm{C}$ 3, which changed from $\delta_{\mathrm{C}} 99.9$ to $\delta_{\mathrm{C}} 72.5$, as well as the coupling pattern of $\mathrm{H}_{3} \mathrm{C}-10$, which appeared as a singlet in $\mathbf{1}$ $\left(\delta_{\mathrm{H}} 1.48\right)$ and as a doublet in $2\left(\delta_{\mathrm{H}} 1.32,7.5 \mathrm{~Hz}\right)$. Long-range correlations observed in the $\mathrm{HMBC}$ data between $\mathrm{H}_{3} \mathrm{C}-10\left(\delta_{\mathrm{H}}\right.$ $1.31)$ and C-4 $\left(\delta_{\mathrm{C}} 175.8\right)$, as well as from $\mathrm{H}-3\left(\delta_{\mathrm{H}} 4.90\right)$ to C-9 $\left(\delta_{\mathrm{C}} 100.4\right)$ and $\mathrm{C}-1\left(\delta_{\mathrm{C}} 171.1\right)$, confirmed the absence of the hydroxy group in C-3. The loss of 16 mass units in 2 relative to compound 1, along with the analysis of the NMR data of $\mathbf{2}$, clearly indicated the reduction of C-3 in 2 . The relative configuration of isoaigialone $\mathrm{B}$ (2) was established by analysis of NOESY 1D data, which showed an NOE between $\mathrm{H}_{3} \mathrm{C}-11$ and $\mathrm{H}_{3} \mathrm{C}-10$, indicating a pseudoaxial position for $\mathrm{H}_{3} \mathrm{C}-11$ in a cis relationship to $\mathrm{CH}_{3}-10$. A dipolar NOE coupling was observed between $\mathrm{H}-6$ and $\mathrm{H}-8$, positioning them in a 1,3 pseudodiaxial relationship. Hence the relative stereochemistry of isoaigialone B (2) was assigned as shown in Figure 2.

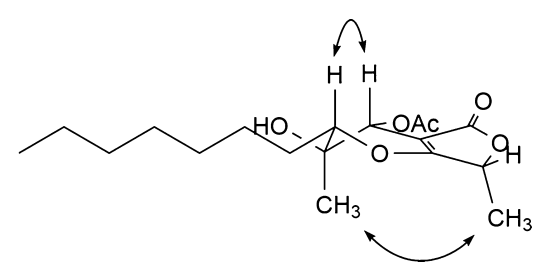

Figure 2. Dipolar couplings (NOEs) observed for isoaigialone B (2).

Compound 3 was also isolated as an optically active, white, amorphous powder. Its molecular formula was established as $\mathrm{C}_{16} \mathrm{H}_{26} \mathrm{O}_{5}$ by HRESIMS analysis, indicating that 3 is isomeric to 2. Indeed, analysis of the NMR data indicated that compound 3 had the same planar structure as $\mathbf{2}$. Considering that the only difference observed between 3 and 2 was the $C-11$ chemical shift $\left(\delta_{\mathrm{C}} 20.4\right.$ in $3, \delta_{\mathrm{C}} 17.6$ in 2$)$, we suggest that 3 is epimeric at C-7 relative to compound 2 .
Compound 4 was identified as the known metabolite aigialone by comparing its spectroscopic data with literature data. ${ }^{14}$ Aigialone was first described from the fungus Aigialus parvus and has not been reported from any other natural source.

Compounds 1-4 were evaluated against Cladosporium cladosporioides and C. sphaerospermum using direct bioautography. ${ }^{16}$ The results showed that 2 and 4 exhibited antifungal activity, with a detection limit of $5 \mu \mathrm{g}$, for both fungi, while compound 3 displayed weak activity (detection limit $>5 \mu \mathrm{g}$ ), with a detection limit of $25 \mu \mathrm{g}$. Nystatin was used as a positive control, showing a detection limit of $1 \mu \mathrm{g}$.

The cytotoxicity of compounds $\mathbf{1 - 4}$ against a human cervical tumor cell line (HeLa) was tested using the MTT assay (Mosmann, 1983); ${ }^{18}$ compound 4 exhibited an $\mathrm{IC}_{50}$ of $50 \mu \mathrm{mol}$ $\mathrm{L}^{-1}$, compound 2 presented an $\mathrm{IC}_{50}$ value of $100 \mu \mathrm{mol} \mathrm{L}-1$, and the other compounds were inactive $\left(\mathrm{IC}_{50}>100 \mu \mathrm{mol} \mathrm{L}^{-1}\right)$. Camptothecin was used as positive control and presented an $\mathrm{IC}_{50}$ of $0.12 \mu \mathrm{mol} \mathrm{L}{ }^{-1}$.

In conclusion, we have isolated three new polyketides, isoaigialones $\mathrm{A}, \mathrm{B}$, and $\mathrm{C}$, from Phaeoacremonium sp. To the best of our knowledge, only one natural metabolite presenting the furo $[3,4-b]$ pyran ring system, named massarilactone $B$, has been previously reported, in this case from the freshwater aquatic fungus Massarina tunicatain. ${ }^{15}$ Compounds $2-4$ are active against the phytopathogenic fungi $C$. cladosporioides and C. sphaerospermum, which suggests that these metabolites may exert a defensive role in $S$. spectabilis host species against microbial pathogens.

\section{EXPERIMENTAL SECTION}

General Experimental Procedures. Optical rotations were measured in $\mathrm{MeOH}$ using a PerkinElmer polarimeter with a sodium lamp operating at $598 \mathrm{~nm}$ and $25^{\circ} \mathrm{C}$. UV spectra were recorded in $\mathrm{MeOH}$ or $\mathrm{CHCl}_{3}$ on a Shimadzu UV-2401 PC spectrophotometer. IR spectra were run on a Nicolet Impact-400 spectrophotometer. ${ }^{1} \mathrm{H}$ (500 $\mathrm{MHz})$ and ${ }^{13} \mathrm{C}(125 \mathrm{MHz}) \mathrm{NMR}$ spectra were recorded on a Varian DRX-500 spectrometer, using tetramethylsilane as internal standard. HRESIMS data were obtained on a Q-TOF mass spectrometer from Bruker maXis, with an electrospray ionization (ESI) interface (Bruker, Fremont, CA, USA).

Analytical HPLC was performed on a Varian Pro Star 230 System with a UV-vis/DAD detector, using a Phenomenex $\mathrm{C}_{18}$ column (250 $\mathrm{mm} \times 4.6 \mathrm{~mm}, 5 \mu \mathrm{m}$ ). Column chromatography (CC) was performed over reversed-phase silica gel $230-400$ mesh (Merck). TLC was performed using Merck silica gel 60 (>230 mesh) and precoated silica gel $60 \mathrm{PF}_{254}$. Spots on TLC plates were visualized under UV light and by spraying with anisaldehyde- $\mathrm{H}_{2} \mathrm{SO}_{4}$ reagent followed by heating at $120{ }^{\circ} \mathrm{C}$. Preparative HPLC was performed on a Varian Prep-Star 400 system, using a Phenomenex $\mathrm{C}_{18}(250 \mathrm{~mm} \times 21.2 \mathrm{~mm}, 10 \mu \mathrm{m})$ preparative column.

Plant Material. Leaves of Senna spectabilis were collected in the Araraquara Cerrado area, in June 2001, Araraquara, Sao Paulo state, Brazil. A voucher specimen number (SILVA $\mathrm{N}^{\circ}$-193) has been deposited in the herbarium of the Botanic Garden of São Paulo, Brazil.

Isolation of the Endophytic Fungus. The fungal strains were isolated from healthy leaves of $S$. spectabilis following a published protocol. ${ }^{17}$ Six strains were obtained. Strains were coded as CL-01 to CL-06 and preserved in sterile water. The fungal strain CL-06 was identified as Phaeoacremonium sp. by Prof. Dr. Ludwig H. Pfenning and Camila P. Nicolli, Federal University of Lavras, based on morphological markers and ITS sequences. The sequence reported has been deposited in the GenBank database (accession no. KY486755). The fungal strain was also deposited at Coleção Micológica de Lavras under the number CML 139, at the Phytopathology Department, Federal University of Lavras, Brazil. 
Growth of Phaeoacremonium sp. and Preparation of the EtOAc Extract. The strain CL-06, identified as Phaeoacremonium sp., was inoculated in a Petri dish containing potato dextrose agar and incubated for 7 days. After this period, preinoculi were incubated in potato dextrose broth ( $5.6 \mathrm{~L}$, total volume) and incubated at $160 \mathrm{rpm}$, under controlled temperature $\left(25^{\circ} \mathrm{C}\right)$ for 28 days. After growth, the broth was separated from the mycelium by filtration and extracted with EtOAc three times (50\% of the broth volume each). The organic layer was evaporated to dryness, to give $866.0 \mathrm{mg}$ of crude extract.

Antifungal Assay. The assay for antifungal potential (bioautography) of the crude AcOEt extract and compounds 1-4 was carried out with the phytopathogenic fungi C. sphaerospermum (Perzig) SPC 491 and C. cladosporioides (Fresen) of Vries SPC 140, using a previously described method. ${ }^{16}$ Both strains are maintained at the Institute of Botany, São Paulo, Brazil. The assays were performed at concentrations of $5,10,20,50$, and $100 \mu \mathrm{g} \mathrm{L}^{-1}$, using nystatin as positive control.

Cytotoxicity Bioassay. The human cervical cancer cell line assay was performed as previously described. ${ }^{18}$ Camptothecin was used as positive control.

Extraction and Isolation. The EtOAc extract $(866.0 \mathrm{mg})$ was fractioned by $\mathrm{CC}$ using reversed-phase silica gel and a gradient of $\mathrm{MeOH}$ in $\mathrm{H}_{2} \mathrm{O}$ as eluent, to give six fractions of $200 \mathrm{~mL}$ each: $\mathrm{MeOH}$ 15\% (FrCL-06-1, $108.0 \mathrm{mg}$ ), $\mathrm{MeOH} 25 \%$ (FrCL-06-2, $83.0 \mathrm{mg}$ ), $\mathrm{MeOH}$ 35\% (FrCL-06-3, $19.4 \mathrm{mg}$ ), $\mathrm{MeOH} 50 \%$ (FrCL-06-4, 26.0 $\mathrm{mg}$ ), $\mathrm{MeOH} 100 \%$ (FrCL-06-5, $553.0 \mathrm{mg}$ ), and $\mathrm{CH}_{2} \mathrm{Cl}_{2}$ (FrCL-06-6, $63.0 \mathrm{mg}$ ). Fraction FrCL-06-5 (553.0 mg) was further purified using reversed-phase preparative HPLC $\left(\mathrm{H}_{2} \mathrm{O} / \mathrm{MeCN}(65: 35), 15.0 \mathrm{~mL}\right.$ $\left.\mathrm{min}^{-1}\right)$, yielding the isoaigialones $1\left(t_{\mathrm{R}}=43 \mathrm{~min} ; 30.0 \mathrm{mg}\right), 2\left(t_{\mathrm{R}}=52\right.$ $\mathrm{min} ; 20.0 \mathrm{mg})$, and $3\left(t_{\mathrm{R}}=65 \mathrm{~min} ; 12.0 \mathrm{mg}\right)$ and aigialone $4\left(t_{\mathrm{R}}=69\right.$ min; $180.0 \mathrm{mg}$ ).

Isoaigialone $A(1)$ : white, amorphous powder; $[\alpha]^{25}-36.0(c 0.38$, $\mathrm{MeOH}) ; \mathrm{UV}(\mathrm{MeOH}) \lambda_{\max }(\log \varepsilon) 235(3.65) \mathrm{nm}$; IR (KBr) $\nu_{\max }$ 3336, 1736, and $1677 \mathrm{~cm}^{-1} ;{ }^{1} \mathrm{H}$ and ${ }^{13} \mathrm{C}$ NMR see Table 1; HRESIMS $m / z 315.1788[\mathrm{M}+\mathrm{H}]^{+}$(calcd for $\mathrm{C}_{17} \mathrm{H}_{26} \mathrm{O}_{6}, 315.1808$ ).

Isoaigialone $B(2)$ : white, amorphous powder; $[\alpha]^{25}-141.5(c$ $\left.0.27, \mathrm{CHCl}_{3}\right)$; IR ( $\left.\mathrm{KBr}\right) \nu_{\max } 3336,1736$, and $1677 \mathrm{~cm}^{-1} ;{ }^{1} \mathrm{H}$ NMR and ${ }^{13} \mathrm{C}$ NMR see Table 1; HRESIMS $m / z 299.1853[\mathrm{M}+\mathrm{H}]^{+}(\mathrm{calcd}$ for $\left.\mathrm{C}_{16} \mathrm{H}_{25} \mathrm{O}_{5}, 299.1858\right)$.

Isoaigialone $C$ (3): white, amorphous powder; $[\alpha]^{25}+39.1(c 0.14$, $\left.\mathrm{CHCl}_{3}\right)$; IR (KBr) $\nu_{\max } 3336,1736$, and $1677 \mathrm{~cm}^{-1} ;{ }^{1} \mathrm{H}$ and ${ }^{13} \mathrm{C}$ NMR see Table 1; HRESIMS $\mathrm{m} / z 321.1677[\mathrm{M}+\mathrm{Na}]^{+}$(calcd for $\mathrm{C}_{16} \mathrm{H}_{26} \mathrm{O}_{5} \mathrm{Na}$, 321.1678).

$\mathrm{X}$-ray Structure Determination of Isoaigialone 1. The X-ray crystallographic data were measured on an Enraf-Nonius KAPPA CCD diffractometer ( $95 \mathrm{~mm} \mathrm{CCD} \mathrm{camera} \mathrm{on} \mathrm{a} \kappa$-goniostat) with a $\mathrm{CCD}$ area detector at 293(2) $\mathrm{K}$ using graphite-monochromated Mo $\mathrm{K} \alpha$ radiation $(\lambda=0.71073 \AA)$. The structure was solved by direct methods and refined by full-matrix least-squares on $F^{2}$ using the program SHELXS-97. ${ }^{19}$ The crystal data are summarized as follows: empirical formula $\mathrm{C}_{16} \mathrm{H}_{24} \mathrm{O}_{6}$; formula weight $312.35 \mathrm{amu}$; monoclinic, space group $P 21, Z=2, a=5.433(1) \AA, b=8.456(1) \AA, c=18.775(3)$ $\AA, \beta=94.864(7)^{\circ}, V=859.4(2) \AA^{3} ; D_{\text {calcd }}=1.207 \mathrm{mg} / \mathrm{m}^{3} ; F(000)=$ $336, \mu=0.092 \mathrm{~mm}^{-1}$; 6387 collected reflections $\left(3.25^{\circ} \leq \theta \leq 27.36^{\circ}\right)$, $-6 \leq h \leq 6,-10 \leq k \leq 9,-21 \leq l \leq 23 ; 2830$ independent reflections $\left(R_{\text {int }}=0.0739\right)$; goodness-of-fit on $F^{2}$ is 1.099 , final $R$ indices for $I>$ $2 \sigma(I), R_{1}=0.0739, w R_{2}=0.1698, R$ indices for all data $R_{1}=0.1345$, $w R_{2}=0.2022$; refining 224 parameters and no restraints; the largest

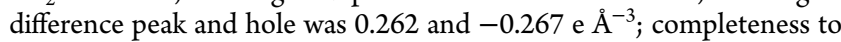
$\theta\left(27.36^{\circ}\right)$. Crystallographic data are deposited with number 763495 at the Cambridge Crystallographic Data Centre, Cambridge, UK.

\section{ASSOCIATED CONTENT}

\section{S Supporting Information}

The Supporting Information is available free of charge on the ACS Publications website at DOI: 10.1021/acs.jnatprod.5b00828.

Selected ${ }^{1} \mathrm{H}$ and ${ }^{13} \mathrm{C}$ NMR, ${ }^{1} \mathrm{H}-{ }^{1} \mathrm{H}$ COSY, HSQC, HMBC, and HRMS spectra of compounds 1-3 (PDF)

\section{AUTHOR INFORMATION}

\section{Corresponding Author}

*Tel: +55-16-3301-9658. Fax: +55-16-3301-6692. E-mail: araujoar@iq.unesp.br (A. R. Araujo).

ORCID -

Angela R. Araujo: 0000-0001-7616-9652

Notes

The authors declare no competing financial interest.

\section{ACKNOWLEDGMENTS}

We gratefully acknowledge the financial support from FAPESP (Fundação de Amparo à Pesquisa do Estado de São Paulo, as part of Biota-FAPESP, the Biodiversity Virtual Institute Program (www.biota.org.br) grant nos. 03/02176-7, 2010/ 52327-5, and 2013/07600-3), CNPq (Conselho Nacional de Desenvolvimento Científico e Tecnológico), and CAPES (Coordenação de Aperfeiçoamento de Pessoal de Nível Superior). M.L.Z. acknowledges FAPESP for the scholarship 2011/03017-6. V.M.C. acknowledge CAPES for a scholarship. The authors would also like to thank Prof. Dr. Roberto G. S. Berlinck for suggestions to improve this study.

\section{REFERENCES}

(1) Kongsaeree, P.; Prabpai, S.; Sriubolmas, N.; Vongvein, C.; Wiyakrutta, S. J. Nat. Prod. 2003, 66, 709-711.

(2) O’Brien, H. E.; Parrent, J. L.; Jackson, J. A.; Moncalvo, J. M.; Vilgalys, R. Appl. Environ. Microbiol. 2005, 71, 5544-5550.

(3) Azevedo, J. L.; Araújo, W. L. Diversity and Applications of Endophytic Fungi Isolated from Tropical Plants. In Fungi Multifaceted Microbes; Ganguli, B. N., Deshmukh, S. K., Eds.; Anamaya Publishers: New Delhi, 2007; p 189.

(4) Gunatilaka, A. A. L. J. Nat. Prod. 2006, 69, 509-526.

(5) Nisa, H.; Kamili, A. N.; Nawchoo, I. A.; Shafi, S.; Shameem, N.; Bandh, S. A. Microb. Pathog. 2015, 82, 50-59.

(6) Gutierrez, R. M. P.; Gonzalez, A. M. N.; Ramirez, A. M. Curr. Med. Chem. 2012, 19, 2992-3030.

(7) Silva, G. H.; Teles, H. L.; Trevisan, H. C.; Young, M. C. M.; Pfenning, L. H.; Eberlin, M. N.; Haddad, R.; Costa Neto, C.; Bolzani, V. S.; Araujo, A. R. J. Braz. Chem. Soc. 2005, 16, 1463-1466.

(8) Silva, G. H.; Teles, H. L.; Zanardi, L. M.; Young, M. C. M.; Haddad, R.; Eberlin, M. N.; Pfenning, L. H.; Costa-Neto, C.; CastroGamboa, I.; Bolzani, V. S.; Araujo, A. R. Phytochemistry 2006, 67, 1964-1969.

(9) Teles, H. L.; Silva, G. H.; Castro-Gamboa, I.; Bolzani, V. S.; Pereira, J. O.; Costa-Neto, C. M.; Haddad, R.; Eberlin, M. N.; Young, M. C. M.; Araújo, A. R. Phytochemistry 2005, 66, 2363-2367.

(10) Gubiani, J. R.; Zeraik, M. L.; Oliveira, C. M.; Ximenes, V. F.; Nogueira, C. R.; Fonseca, L. M.; Silva, D. H. S.; Bolzani, V. S.; Araujo, A. R. J. Nat. Prod. 2014, 77, 668-672.

(11) Inácio, M. L.; Silva, G. H.; Teles, H. L.; Trevisan, H. C.; Cavalheiro, A. J.; Bolzani, V.; da, S.; Young, M. C.M.; Pfenning, L. H.; Araújo, Â. R. Biochem. Syst. Ecol. 2006, 34, 822-824.

(12) Chapla, V. M.; Zeraik, M. L.; Ximenes, V. F.; Zanardi, L. M.; Lopes, M. N.; Cavalheiro, A. J.; Silva, D. H. S; Young, M. C. M.; Fonseca, L. M.; Bolzani, V. S.; Araújo, A. R. Molecules 2014, 19, 65976608.

(13) Strobel, G. A.; Daisy, B.; Castillo, U.; Harper, J. J. Nat. Prod. 2004, 67, 257-268.

(14) Vongvilai, P.; Isaka, M.; Kittakoop, P.; Srikitikulchai, P.; Kongsaeree, P.; Thebtaranonth, Y. J. Nat. Prod. 2004, 67, 457-460.

(15) Oh, H.; Swenson, D. C.; Gloer, J. B.; Shearer, C. A. Tetrahedron Lett. 2001, 42, 975-977.

(16) Rhalison, L.; Hamburger, M.; Hostettmann, K.; Monod, M.; Frenk, E. Phytochem. Anal. 1991, 5, 199-203.

(17) Maier, W.; Hammer, K.; Dammann, U.; Schulz, B.; Strack, D. Planta 1997, 202, 36-42. 
(18) Mosmann, T. J. Immunol. Methods 1983, 65, 55-63.

(19) Sheldrick, G. M. SHELXL-97, Program for the Refinement of Crystal Structures; University of Göttingen: Göttingen, Germany, 1997. 